\title{
DEMOGRAPHIC AND LIVING CONDITIONS OF TUBERCULOSIS PATIENTS RECEIVING DIRECTLY OBSERVED THERAPY SHORT- COURSE (DOTS) IN CALABAR, NIGERIA
}

\begin{abstract}
ANNE E. ASUQUO, LYDIA N. ABIA-BASSEY, B. P. THUMAMO, N. C. OSUCHUKWU, REGINA EJEMOT-NWADIARO, ANGELA OYO-ITA AND MARTIN M. MEREMIKWU
\end{abstract}

(Received 27 August, 2007; Revision Accepted 12 March, 2008)

\begin{abstract}
Understanding the role of poverty in the continued epidemic of TB in developing countries will provide useful information for the improvement of TB control activities in these areas. A survey of the living conditions of 274 TB patients registered for DOTS at the National Tuberculosis Control Program Centre of the Lawrence Henshaw Memorial hospital Calabar and the Endemic Disease Clinic of the University of Calabar Teaching Hospital, Calabar was conducted to verify the view that poverty influences the incidence and outcome of TB. Using a structured pre-tested self- or interview- administered questionnaire, data were collected from a sample of 274 subjects: males $(162 / 59 \%)$ and females $(112 / 41 \%)$ within the economically viable age of 15-55 years. Results showed that the number of TB patients in the study decreased with increasing number of children of $\geq 3$ in the households of subjects. The average income of the $244(89 \%)$ income earners was N6,045.00 (\$46.50) a month. Of this number, $170(70 \%)$ earned less than N5,000 (\$37.00) monthly. Thirty $(11 \%)$ had no reliable means of income. Unemployed persons and students constituted the highest percentage of the subjects $(18 \%$ and $17 \%$ respectively). A low socio-economic status and poor housing conditions typified by overcrowding and poor ventilation characterized the TB patients in this study. TB control programs anchored by government and non-governmental agencies need to address poverty reduction as part of their intervention strategies.
\end{abstract}

KEYWORDS: TB patients, Demography, Socio-economic status, Housing conditions, Nigeria.

\section{INTRODUCTION}

Evidence abound that poverty influences the incidence and outcome of tuberculosis. Although the current Human Immunodeficiency Virus/Acquired Immune Deficiency Syndrome (HIVIAIDS) pandemic in the developing countries is substantially blamed for the continued rise in TB case notification, the role of poverty and its attendant consequences cannot be ignored. Factors including, increased poverty, social upheaval and crowded living conditions in developing countries and inner city populations in developed countries are increasingly implicated in the spread of TB

Anne E. Asuquo, Department of Medical Microbiology and Parasitology, University of Calabar, Calabar,Nigeria. Lydia N Abia-Bassey, Department of Medical Microbiology and Parasitology, University of Calabar, Nigeria.

Benjamin P Thumamo, Department of Medical Microbiology and Parasitology, University of Calabar, Nigeria.

Nelson C. Osuchukwu, Dept. of Environmental Health Sciences, University of Calabar, Nigeria.

Regina Ejemot-Nwadiaro, Dept. of Environmental Health Sciences, University of Calabar, Calabar, Nigeria.

Angela Oyo-Ita, Department of Community Medicine, University of Calabar, Calabar, Nigeria.

Martin M. Meremikwu, Department of Paediatrics, University of Calabar, Calabar, Nigeria. 
(Basic Facts on TB, 2002). Poor people are especially vulnerable to TB because of their underlying health status, adverse living conditions (overcrowded and substandard living or working conditions, poor nutrition, concomitant infection with other diseases such as HIVIAIDS) and their limited access to health facilities (The Stop TB Initiative, 2000). It is estimated that over $50 \%$ of new TB patients are living on less than $\$ 2$ per day (The Stop TB Partnership/ IPA, 2001). Low income, with GNP per capita of less than $\$ 760$ is a major characteristic of 18 of the 22 highest TB burden countries (World Bank, 2000). According to Reider (1999), while TB is not exclusively a disease of the poor, deprivation associated with poverty increases the risk of infection and development of disease. There are clear associations between risk of TB and malnutrition and overcrowding which emanate from low socio-economic status (Long, 1999; Comstock and Cauthen, 1992). According to Colston (1995), TB acts as a barometer for social change, it increases when living conditions deteriorate and decreases as they improve. This study which investigated the socio-economic status and living conditions of tuberculosis patients receiving treatment at a National TB Control Program (NTBLCP) treatment centre was an attempt to fill the gap in the dearth of indigenous data linking TB to poverty in Nigeria.

\section{METHODS}

\section{Study Population}

The subjects in this study consist of 274 tuberculosis patients registered for directly observed therapy short-course (DOTS) on the NTBCLP. The subjects who were drawn from the Lawrence Henshaw Memorial hospital TB Centre, Calabar and the Endemic Disease Clinic of the University of Calabar Teaching Hospital, Calabar included 162 males and 112 females all aged between 15 and 55 years. Through the administration of structured questionnaires and personal interviews, the demography, socio-economic status and type of housing of each patient was investigated. The structure and quality of houses as well as monthly income earned were used as indices of the socio-economic status of the subjects. Responses to the questions were analyzed using the descriptive statistical method.

\section{RESULTS}

\section{A. Demography}

Data obtained from responses to questions posed in the questionnaires (Table 1) indicated that $162(59 \%)$ were males while $112(41 \%)$ were females. The ages of the patients ranged between 15 to $>55$ years $($ mean $=35.7)$. Of the 274 patients, 162 $(59 \%)$ were married and $112(41 \%)$ were single. A total of $164(60 \%)$ of the subjects had between 1 and 10 children (mean $=5.5$ ) while $110(40 \%)$ of the subjects had no children.

Table 1: Demography of TB patients Studied in Calabar

\begin{tabular}{|c|c|c|c|c|c|c|c|c|c|c|c|c|c|c|}
\hline \multicolumn{5}{|c|}{ Age (years) } & \multicolumn{2}{|c|}{ Sex } & \multicolumn{2}{|c|}{ Marital status } & \multicolumn{6}{|c|}{ Number of children } \\
\hline $15-24$ & $\begin{array}{l}25- \\
34\end{array}$ & $\begin{array}{l}35- \\
44\end{array}$ & $\begin{array}{l}44- \\
55\end{array}$ & $>55$ & Male & Female & $\begin{array}{c}\text { Marri } \\
\text { ed }\end{array}$ & $\begin{array}{c}\text { Singl } \\
\mathrm{e}\end{array}$ & None & $1-2$ & 3-4 & $5-6$ & $7-8$ & $>8$ \\
\hline $48(17.5 \%)$ & $\begin{array}{c}93 \\
(33.9 \\
\%)\end{array}$ & $\begin{array}{c}65 \\
(23.7 \\
\%)\end{array}$ & $\begin{array}{l}50 \\
(18.2 \\
\%)\end{array}$ & $\begin{array}{c}18 \\
(6.6 \\
\%)\end{array}$ & $\begin{array}{c}162 \\
(59.1 \%)\end{array}$ & $\begin{array}{c}112 \\
(40.9 \%)\end{array}$ & $\begin{array}{c}162 \\
(59.1 \\
\%)\end{array}$ & $\begin{array}{c}112 \\
(40.9 \\
\%)\end{array}$ & $\begin{array}{c}110 \\
(40.2 \\
\%)\end{array}$ & $\begin{array}{c}28 \\
(10.2 \\
\%)\end{array}$ & $\begin{array}{c}66 \\
(24.1 \%)\end{array}$ & $\begin{array}{c}42 \\
(15 . \\
3 \%)\end{array}$ & $\begin{array}{c}26 \\
(9.5 \\
\%)\end{array}$ & $\begin{array}{c}2 \\
(0.7 \\
\%)\end{array}$ \\
\hline
\end{tabular}




\section{B. Socio-Economic Characteristics and}

\section{Educational Qualification of TB Patients}

The TB patients were engaged in a broad range of low- income occupations including low cadre civil service oriented jobs $(5.8 \%)$, labourers at construction sites (5.1\%), farming $(13.1 \%)$, driving and trading (11.7 and $13.9 \%$ ) (Figure 1). Others (totaling $15.4 \%)$ included 6 hairdressers $(2.2 \%), 4$ military personnel $(1.5 \%), 6$ retired civil servants $(2.2 \%)$, and the remaining $9.5 \%$ did not indicate their occupation. Unemployed persons and students constituted $18.2 \%$ and $16.8 \%$ respectively.

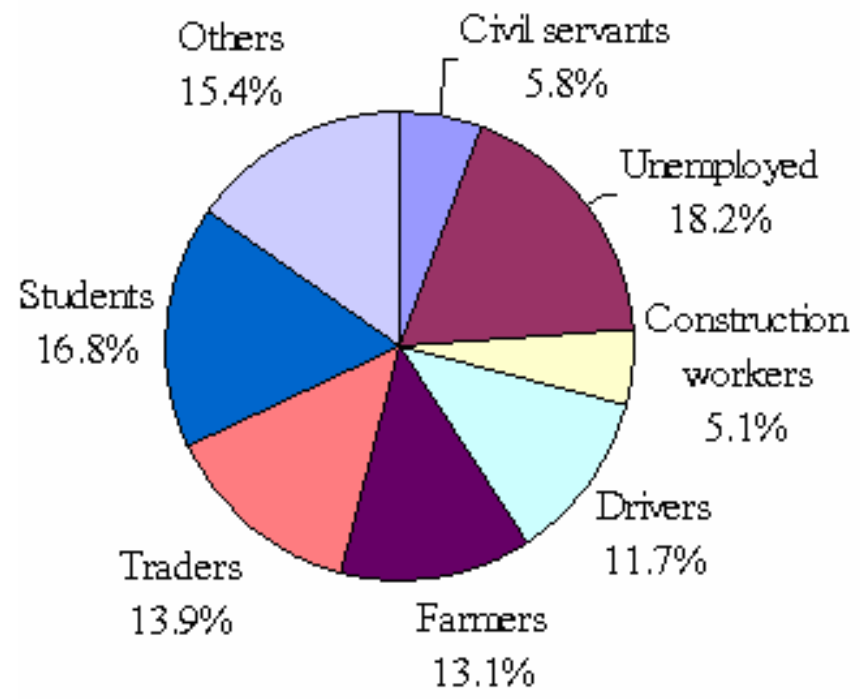

Fig. 1: Occupation of TB patients

The total monthly income of the patients showed that $30(11 \%)$ of the patients had no reliable source of income, while the mean income of the remaining $244(89 \%)$ income earners was $\mathrm{N} 6045$ (\$46.5). A breakdown of the income earners showed that $170(70 \%)$ earn less than N5000 (\$37.00) monthly and $52(21 \%)$ earned less than N10,000 (\$74.00) per month. Another 18 (7.4\%) earned between N10,000 (\$74.00) and N50,000 $(\$ 370)$. Four $(1.6 \%)$ of the patients earned more than N50,000 (\$370.00) monthly. The educational qualification of the patients showed that $34(12 \%)$ had no formal education, 104 (38\%) completed primary education, while $78 \quad(28.5 \%)$ attained secondary education. Fifty-six subjects had attained tertiary education with qualifications ranging from Bachelor of Science or Arts, Ordinary National Diploma (OND) or Higher National Diploma (HND).

\section{Housing Conditions}

Of the 274 subjects investigated in this study, $132(48.2 \%)$ lived in concrete houses, $82(30 \%)$ lived in mud-walled houses with cement plastering, and $54(20 \%)$ lived in mud-walled houses with thatch roofing (Table 2).

Table 2: Housing Structure of TB patients Studied in Calabar

\begin{tabular}{|c|c|c|c|c|c|c|c|c|}
\hline \multicolumn{4}{|c|}{ Type of house } & \multicolumn{2}{c|}{ Type of Flooring } & \multicolumn{2}{c|}{ Presence of ceiling } \\
\hline Concrete & $\begin{array}{c}\text { Mud wall } \\
\text { with zinc }\end{array}$ & $\begin{array}{c}\text { Mud with } \\
\text { cement } \\
\text { plastering }\end{array}$ & Thatch & $\begin{array}{c}\text { Cement } \\
\text { over mud }\end{array}$ & Concrete & Mud & Yes & No \\
\hline 132 & 6 & $82(29.9 \%)$ & $\begin{array}{c}54 \\
(19.7 \%)\end{array}$ & $\begin{array}{c}98 \\
(35.8 \%)\end{array}$ & $\begin{array}{c}134 \\
(48.9 \%)\end{array}$ & $\begin{array}{c}42 \\
(15.3 \%)\end{array}$ & $\begin{array}{c}176 \\
(64.2 \%)\end{array}$ & $\begin{array}{c}98 \\
(35.8 \%)\end{array}$ \\
\hline
\end{tabular}


One hundred and seventy six (64\%) of the houses were sealed with asbestos ceiling sheets while the rest $(35.8 \%)$ were not sealed leaving a gap between the roof and the walls. The flooring in $134(49 \%)$ of the houses was made of concrete with cement plastering, $98(36 \%)$ had floors made of mud with cement finishing while $42(15 \%)$ patients lived in houses with mud flooring. Only 2 $(0.7 \%)$ TB patients did not share their rooms with another occupant; $78(28.5 \%)$ of the patients shared their rooms with 1 to 3 persons, $136(49.6 \%)$ with 4 to 6 persons, 54
(19.7\%) with 7 to 10 persons and $4(1.5 \%)$ lived with more than 10 persons in their household (Figure 2). Overall, a mean value of 5.4 people shared rooms or households with the TB patients in this study. More than 220 respondents lived with at least 5 other households in the same compound, and 160 patients were from family size of variable sizes who lived in one room apartments (Table 3). Investigation into the status of ventilation in the houses showed that 206 of the 274 patients lived in poorly ventilated houses (lacking cross ventilation) with only one window.

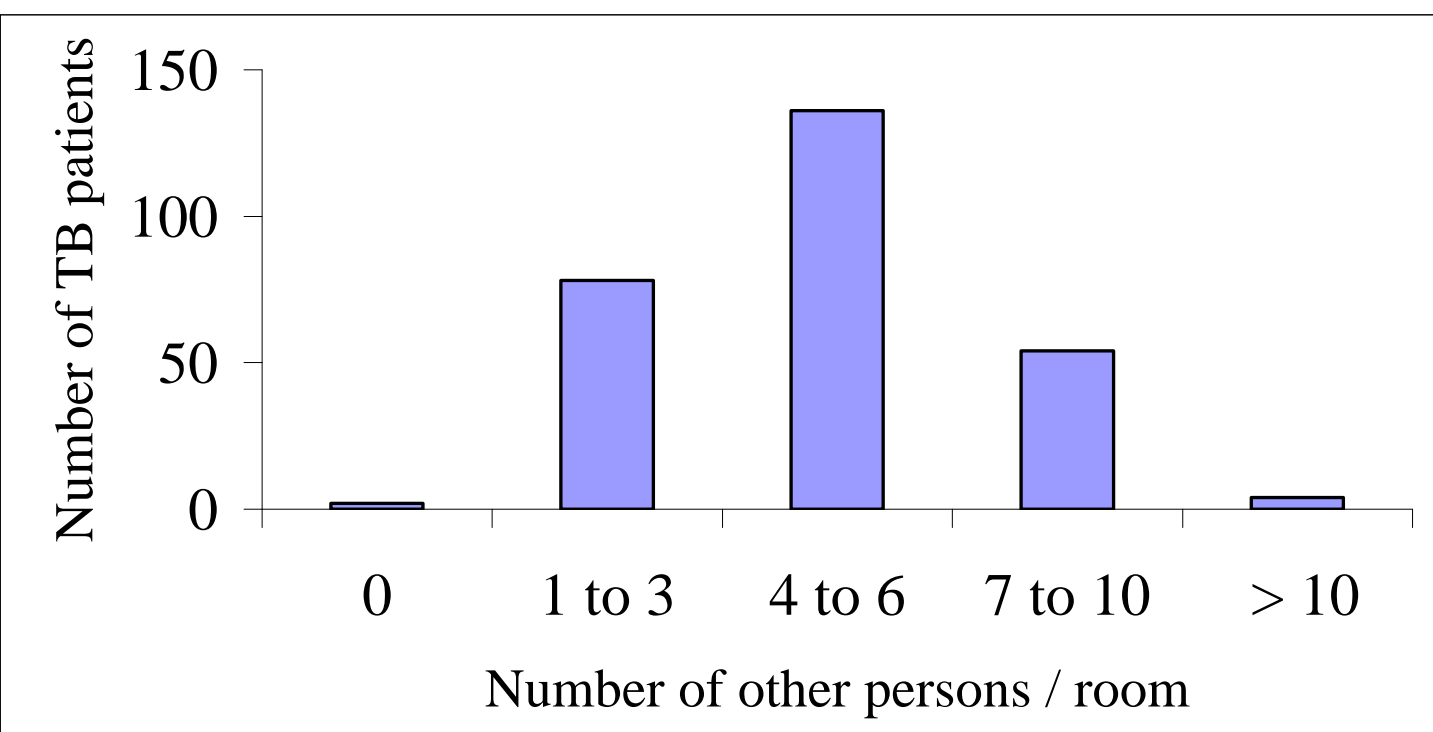

Figure 2: Number of TB patients sharing rooms with other persons

Table 3: House design and number of houses per compound of TB Patients

\begin{tabular}{|c|c|c|c|c|c|c|c|}
\hline \multicolumn{4}{|l|}{} & \multicolumn{3}{|c|}{ Number of rooms/flats in a compound } \\
\hline $\begin{array}{c}\text { House design } \\
\text { Room }\end{array}$ & $\begin{array}{c}1 \\
\text { bedroom } \\
\text { flat }\end{array}$ & $\begin{array}{c}2 \\
\text { bedrooms } \\
\text { flat }\end{array}$ & $\begin{array}{c}3-4 \\
\text { bedrooms } \\
\text { flat }\end{array}$ & 1 & $2-4$ & $5-7$ & $>7$ \\
160 & 44 & $\begin{array}{c}38 \\
(13.9 \%)\end{array}$ & $\begin{array}{c}32 \\
(11.7 \%)\end{array}$ & $\begin{array}{c}10 \\
(3.6 \%)\end{array}$ & $\begin{array}{c}40 \\
(14.6 \%)\end{array}$ & $\begin{array}{c}40 \\
(14.6 \%)\end{array}$ & $\begin{array}{c}184 \\
(67.2 \%)\end{array}$ \\
\hline
\end{tabular}




\section{DISCUSSION AND CONCLUSION}

\section{Demographic Characteristics}

Male sex has been identified as a risk factor for TB (Gustafson et al., 2003; Lienhardt et al., 2005). Globally, there are 1.7 times as many male reported pulmonary TB cases annually as female cases (WHO, 2001). The higher prevalence of TB among male in this study corroborates these as well as other studies reporting higher incidence in men (Lienhardt et al., 2003). It is still unclear whether the difference is behavioural, socioeconomic, or biological (Diwan, Thorson \& Winkvist, 1998). Some studies suggest that the higher incidence of TB in male may be due to inequities in access to care, making women less likely than men to be tested and treated for TB (Hudelson, 1996), or may reflect underlying epidemiological differences in TB between male and female (Borgdorff et al. 2000) or a combination of both (Diwan, Thorson \& Winkvist, 1998). However, with the current HIV epidemic, which disproportionately affects women, it is feared that the proportion of female TB cases will increase in the worst HIVIAIDS affected areas (UNAIDS, 2001).

There is evidence that TB is more common among single men than married men (Christensen et al., 1978; Tekkel et al., 2002; Lienhardt et al., 2005). A higher incidence of TB was seen in this study among married persons compared to singles. While marriage may not be a risk factor for the acquisition of TB, the large households and poor housing conditions among married patients recorded in this study constitute important determinants of high prevalence of TB among couples and other members of their households. This study also demonstrated a decrease in the number of TB patients with increasing number of $\geq 3$ children in the household. A similar decrease was reported by Gustafson et al (2003) who found that people living without children or with adults had a higher risk of developing TB than people living in households with children. A possible explanation for this finding is that contact with children offers some protection through immune stimulation from exposure to childhood infection (Gustafson et al., 2003). The authors also suggested that this may be partly responsible for why women are less likely to develop TB than men.

About $93 \%$ of the TB patients in this study were aged between 15-55 years. It has been shown that more than $75 \%$ of TBrelated disease and deaths occur among people between the ages of 15 to 54 years the most economically active segment of the population (The Stop TB Initiative, 2000). Worldwide, tuberculosis affects the most productive age group (Central TB Division TB India, 2004). Of the 112 female TB patients in this study, $77(69 \%)$ were aged between 15 and 44 years. TB is a leading cause of mortality among women of reproductive age, resulting in more than 1 million deaths annually (WHO, 2001).

\section{Socio-economic Status}

Poverty contributes to the spread of TB and TB contributes to the persistence of poverty (Stop TB Partnership, 2002; Dye et al., 1999). The economic burden of TB disease has been shown to be higher on the poor because they have little disposable income due to the nature of their livelihood activities, which usually include daily wage labour and petty trading. (Nair et al. 1997; Rajeswari et al.1999). Most of the TB patients in this study may be classified as low- income earners as they were found in a variety of low income generating occupations such as driving, petty trading, subsistence farming, etc. It is worthy of note that although 56 subjects had attained tertiary educational qualifications, only 22 earned monthly income of $\mathrm{N} 10,000$ (\$74.00) or more; an indication of low remunerations or unemployment for more than half of these category of subjects.

Although small, an association between unemployment and the rate of increase in TB 
case notification was established in 32 London boroughs between 1982 and 1991 (Mangtani et al., 1995). More than $18 \%$ of TB patients in this study were unemployed. This is not surprising as about $78 \%$ of the subjects have either no more than secondary education or no education at all. This may be the reason why at least $200(73 \%)$ are without any reliable source of income or earn less than N5000 monthly. Furthermore, about $53 \%$ of the 162 married patients have at least 3 children. Sustaining a family of at least 5 on a monthly income of less than N5000 (\$40) indicates conditions of abject poverty.

Our findings however, contrast with reports of two studies in South Africa which failed to show an association between low socioeconomic level and active TB in adults (Schoeman, Westaway \& Neethling, 1991; Glynn et al., 2000 ). Major risk factors for TB in Estonia were related to poverty and low socio-economic status. Specifically, lower educational level, low income, current unemployment, shortage of food, among other factors (Tekkel et al., 2002). Studies in New York City from 1984-1992 showed that neighbourhoods with declining income from 1980-1990 had larger increases in TB incidence than those with increasing income (Graham Barr et al., 2001).

\section{Housing Conditions}

Housing quality may be indicative of poor living conditions. Mud houses with thatch roofing, lacking indoor facilities such as kitchens, bathrooms, presence of ceiling and corrugated iron sheets have been used as indicators of poor living conditions (Gustafson et al., 2003). The authors demonstrated an increased risk for TB associated with the above housing conditions. Overcrowding was a major feature in the housing conditions of TB patients in this study. About $50 \%$ of TB patients studied shared rooms with 4 to 6 other persons, $58 \%$ lived in only one room and more than $67 \%$ lived in crowded compounds with at least 7 other households in rooms facing each other and separated by long narrow corridors. This has grave implications for the spread of TB. In a study involving TB patients and healthy individuals drawn from households that were similar in terms of family size and type of housing conditions, it was observed that there was a higher frequency of TB in households of index TB patients (Claessens et al., 2002)

Adult crowding and poor housing conditions were important risk factors for TB in Bissau (Gustafson et al., 2003). The conditions of overcrowding seen in this study imply that several persons are in contact with these TB patients and are at risk of contracting TB infection. Particularly vulnerable are the children in these households. The World Health Organization (WHO, 2006) states that over 250,000 children develop TB annually and 100,000 will continue to die each year from TB. They are particularly vulnerable to TB infection because of frequent household contacts (The Stop TB Partnership 2001; World Health Organization, 2006). Usually adults transmit TB to children and TB infection in children who are in contact with infectious TB cases was seen to be directly related to the intensity of the exposure of the child to the index case (Lienhardt et al., 2003). Children living in poor socio-economic conditions account for a notable proportion of morbidity caused by TB in Cape Town (van Rie, 1999). Efforts to improve TB control must target not only adults but children as well, through screening of child contacts of adult cases.

Illness and death from TB reinforce and deepen poverty in many communities. This study demonstrated that in Calabar, Nigeria, TB is common among low income earners living under overcrowded, poor housing conditions. Although TB among households with children appeared to decrease with increase in the number of children, in such households, children are at higher risk of acquiring the infection. Governments and TB 
control programs should emphasize poverty reduction and intensify tracing of adult TB cases and child contacts of adult cases in their intervention strategies.

\section{ACKNOWLEDGEMENT}

We wish to acknowledge with thanks the invaluable contributions of the following persons: Ibokette who assisted in data collection and the staff of the National TB Control Unit in Calabar who mobilized their patients for us. We are also grateful to the patients that accepted to participate in the study.

\section{REFERENCES}

Borgdorff, M., Nargelkerke, N., Dye, C., Nunn, P., 2000. Gender and Tuberculosis: a Comparison of Prevalence surveys with Notification data to explore Sex Differences in Case Detection". Intl. J. Tubercl. Lung. Dis. 4(2):123-132

Central, T. B Division TB India 2004. RNTCP Status Report. Directorate of Health Services, Ministry of Health and Family Welfare, Nirman Bhavan, New Delhi 110011.

Christensen O, Bjartveit K., Dahlstrom G. 1978. Tuberculosis Situation in the Scandinavian Countries. Scand. J. Respir. Dis. Suppl 102:19-40.

Claessens, N. J, Gausi, F. F, Meijnen S, Weismuller, M. M, Salaniponi, F. M, Harries, A. D., 2002. High frequency of tuberculosis in households of index TB patients. Int. J. Tubercl. Lung Dis. 6(3):181-2.

Colston, J. O., 1995. Tuberculosis: the Return of the Great White Plague. National Institute for Medical Research. Mill Hill Essays.

Diwan, W., Thorson, A., and Winkvist, A., 1998. (eds). Gender and Tuberculosis. NHV
Report 1998. Göteborg: Nordic School of Public Health.

Dye, C., Scheele, S., Dolphin P., Raviglione, M.C.,1999. Consensus Statement. Global Burden of Tuberculosis: Estimated Incidence, Prevalence, and Mortality by Country. WHO Global Surveillance and Monitoring Project. JAMA 282:677-86.

Glynn, J. R., Warndorff, D. K., Malema, S. S., et al 2000. Tuberculosis: association with HIV and socio-economic status in Malawi. Trans. R. Soc. Trop. Med. Hygiene 94: 500-503.

Graham Barr, R., Diez-Roux, A. V., Knirsch, C. A., Pablos-Méndez, A. 2001. Neighbourhood Poverty and the Resurgence of Tuberculosis in New York City, 1984-1992. American J. of Public Health., 91(9): 1487-1493.

Hudelson, P., 1996. Gender Differentials in Tuberculosis: The Role of socio economic and cultural factors. Tubercl. Lung Dis. 77(5):391-400.

Lienhardt C, K Fielding, JS Sillah, B Bah, P Gustafson, D Warndorff, M. Palayew, I Lisse, S Donkor, S Diallo, K Manneh, R Adegbola, $P$ Aaby, O Bah-Sow, S Bennett and $K$ McAdam 2005. Investigation of the risk factors for tuberculosis: a casecontrol study in three countries in West Africa International Journal of Epidemiology 34(4):914-923;

Lienhardt C, Sillah J, Fielding K, Donkor S, Manneh K, Warndorff D, Bennett S, McAdam K., 2003. Risk factors for tuberculosis infection in children in contact with infectious tuberculosis cases in the Gambia, West Africa. Pediatrics 111(5 Pt 1): e608-14.

Lienhardt Christian, Katherine Fielding, Jackson Sillah, Abdulaye Tunkara, Simon Donkor, Kebba Manneh, David Warndorff, 
Keith P. McAdam and Steve Bennett. 2003. Risk Factors for Tuberculosis Infection in Sub-Saharan Africa A Contact Study in The Gambia American Journal of Respiratory and Critical Care Medicine 168: 448 455.

Long, N. H, Johansson, E., Winkvist A, Diwan, V., 1999. International Journal Tuberculosis and Lung Diseases; 3 : 388-93.

Mangtani, P., Watson, J. M., Rodrigues, L. C., 1995. Socio-economic Deprivation and Notification Rates of Tuberculosis in London During 1982-91. BMJ 310:963-966 (April 15)

Nair, D.M., George, A., et al., Chacko, K.T.,1997. Tuberculosis in Bombay: New Insights from Poor Urban Patients (research report). "Health Policy and Planning 12(1): 77-85.

Gustafson Per, Gomes, V. F., Vieira., Rabna P., Seng, R., et al. Johansson P., Sandström, A., Norberg, R., Lisse, I., Samb, B., Aaby, P and Nauclér. 2003. Tuberculosis in Bissau: incidence and Risk Factors in an Urban Community in SubSaharan Africa. Intl. J. Epidemiol. 33(1): 163-172.

Rajeswari R, Balasubramanian R, Muniyandi $M$, et al., 1999. Socio-Economic impact of tuberculosis on patient and family in India. Intl. J. Tubercl. Lung Dis. 3:869-877.

Reider, H. L., 1999. Epidemiological Basis of Tuberculosis Control. Paris, Intl Union Against Tuberculosis and Lung Disease.

Schoeman, J.H., Westaway, M.S. and Neethling A., 1991. The Relationship between Socio-economic Factors and Pulmonary Tuberculosis. Intl. J. Epidemiol. 20:435-40.

Tekkel, M., Rahu, M., Loit, H.M., Baburin, A. 2002. Risk Factors for Pulmonary Tuberculosis in Estonia. The Intl. J.Tuberculosis and Lung Disease 6(10): 887-894(8).

The Stop TB Partnership 2002. Stop TB, Fight Poverty. Basic Facts on TB March 24, 2002.

The Stop TB Initiative, 2000 Series 2000. The Economic Impacts of Tuberculosis Presented at the Ministerial Conference, Amsterdam. March 22-24, 2000.

The Stop TB Partnership/ IPA 2001. Tuberculosis and Children.

UNAIDS 2001. UNAIDS Fact Sheet, Kenya, UNAIDS.

Van Rie, A., Beyers, N., Gie, R.P., Kunneke, M., Zietsman L., Donald, P.R., 1999. Childhood Tuberculosis in an Urban Population of South Africa: Burden and Risk Factors. Arch. Dis. Child 80:433-37.

World Bank. 2000. World development indicators. Washington, D.C., The World Bank.

World Health Organization. 2006. Communicable diseases: TB and children Fact Sheet; April 2006.

World Health Organization 2001. Global Tuberculosis Control. Geneva, Switzerland: WHO. WHO/ CDS /TB /2001.287.

World Health Organization 2000. Research for Action: understanding and controlling tuberculosis in India. Geneva: World Health Organization. 